\title{
Discussion and Practice on Bilingual Teaching of the Course "Marine Business and Maritime Law"
}

\author{
Yuan Gao, Guoyou Jiang \\ Shandong Jiaotong University, Weihai, China
}

Keywords: ocean transportation business and maritime law; bilingual teaching

\begin{abstract}
The Maritime Business and Maritime Law is a compulsory course for the nautical technology major of the Maritime College of Shandong Jiaotong University. The knowledge and content designed by this course has strong foreign-related and professionalism. The implementation of bilingual teaching can adapt to the development needs of the internationalization trend of higher education in China, and it is also an important way to cultivate export-oriented talents with international exchange and competitiveness. In order to better cultivate international high-level nautical talents, this group actively promotes the bilingual teaching mode of the course. Based on the discussion and practice of bilingual teaching of the course, the team summarizes the experience and deficiencies in order to cultivate faster. meets the cutting-edge compound of the amendment.
\end{abstract}

\section{Characteristics of the "Marine business and Maritime Law"}

The Maritime Business and Maritime Law is an old and broad study Branch, many countries give high research and development in this subject. Pay attention to it. It adjusts the relationship between ship relations and sea freight. And the ship is sailing on a global scale, which makes the shipping industry. The object of adjustment of the Ministry of Commerce and Maritime Law has a natural international nature. The shipping business and the maritime law itself have international characteristics.

The international standardization of shipping business and maritime law is very high. There are a large number of international companies in the field. Even in areas where there is no international convention, it often exists World-wide international practices, such as York in the general averageAntwerp Rules, etc. Due to international conventions and international influence of the practice, the maritime legislation in each country often presents highly consistent, the "Marine Law" introduced by China in 1992 is large. Drawing on the international practices and conventions that were prevailing at the time, and referring to the domestic legislation of developed countries, it is considered to be China at that time. The most internationally codified code. China as a marine shipping large countries, related industries and institutions should pay more attention to the teaching of the course and research. China wants to change from a shipping power to a shipping strong country requires a large number of highly qualified shipping professionals, including the law talent. And the cultivation of these talents is inseparable from the school teaching, in order to cultivate talents with international competitiveness, the reform of bilingual teaching in the Maritime Business and Maritime Law is imperative.

\section{The necessity of bilingual teaching in Maritime Business and Maritime Law}

The international characteristics of maritime law determine the bilingual teaching of maritime law and the necessity of learning. On the one hand, bilingual teaching is conducive to improving students. Foreign language ability to improve students' international communication and competitiveness; On the other hand, bilingual teaching is conducive to students to better understand the maritime law. The provisions of the provisions of the article, because many of the provisions of China's maritime law are derived from international conventions or in other countries' legislation, some provisions directly article translation into Chinese, bilingual teaching can make students deeper understand the background and interpretation of the provisions. 


\section{Bilingual Teaching Practice of Maritime Business and Maritime Law}

\subsection{Course setting and selection of teaching materials}

Due to the relatively tight curriculum of the maritime profession, the maritime business and maritime law course is arranged for only one semester of 60 class hours, which is scheduled for the first semester of junior year. During this period, most of the students passed the four-level examination, and some have passed the sixth-level examination. With a relatively good English foundation, bilingual teaching is relatively difficult for students, which can effectively reduce the students. Difficulty in the beginning of bilingual teaching. In the selection of teaching materials, we adopted the "sea" edited by Guo Ping. Transportation Business and Maritime Law, the book is in the ocean transportation business and maritime business law has its own unique insights, detailed content, classic cases, It has always been a classic bibliography in the industry. In use, For the content of the teaching materials, a relatively complete bilingual teaching courseware has been made. The members of the course group are teachers of the foreign language department, and the law teachers and maritime professional teachers, everyone work together to make courseware be as perfect as possible.

\subsection{Bilingual teaching method classroom practice}

\subsubsection{Use of bilingual teaching methods}

In the classroom teaching process, we mainly use "Bilingual over" mode (Transitional Bilingual Model ). In order to make students' professional knowledge more solid and appropriate. Language teaching courses, some of the more professional terms in the course, Give accurate definitions in Chinese and deepen students' knowledge of the course cognition. Of course, most of the time is taught in English, when preparing for class. The vocabulary you choose is as simple as possible, so that everyone can learn professionally. At the same time, I have improved my foreign language level by the way.

\subsubsection{Application of multimedia courseware}

In the bilingual teaching process of the Maritime Business and Maritime Law, we also make full use of the existing multimedia teaching equipment, and use the bilingual teaching courseware produced by the members of this group during class. The courseware has detailed the various business relationships, contents, classifications, etc., and students will see the knowledge they have learned at a glance. In addition, there are a large number of case videos and pictures on the courseware, which can stimulate students' interest in learning.

\section{Thinking and Suggestions on Bilingual Teaching in Maritime Business and Maritime Law}

\subsection{Target Orientation of Bilingual Teaching in Maritime Business and Maritime Law}

The course of the Maritime Business and Maritime Law is to teach students the main content of international trade terms, shipping methods such as ocean shipping vessels, ship security rights, and sea cargo transportation contracts, so as to improve students' problem-solving problems. Ability . Its international characteristics determine its inevitability for English requirements. Bilingual teaching is imperative due to lack of class time, lack of information and the needs of the times. However, we must deal with the relationship between "teaching language" and "language teaching", and distinguish the primary and secondary. The purpose of bilingual teaching reform is to enable students to better understand relevant knowledge and improve their foreign language proficiency.

\subsection{Further improve the construction of bilingual teaching resources (textbooks, courseware)}

The importance of teaching resources to teaching is self-evident. We need to constantly update and enrich the teaching resources in our hands, appropriately increase the introduction of the original texts of international regulations, and pay attention to the current situation to integrate the latest case accidents into our own courseware. In the process of introduction, it is necessary to pay 
attention to the typicality and representativeness of the case, which should be consistent with the legal environment and business environment familiar to the maritime students.

\subsection{Increase the training of teachers in bilingual teaching}

The main body of bilingual teaching is students, but the organizers and the conductors are teachers. Teachers are still the main factors determining the success or failure of bilingual teaching. Bilingual teaching teachers must not only have certain teaching skills and a high level of professionalism, but also be able to express fluently in the content of the courses taught in English. This requires the school to increase the training of this aspect. First of all, in English, the current teacher's English foundation is still good. What is needed is self-reinforcing. Pay more attention to the maintenance and training of foreign language to better serve the classroom. On the other hand, in professional business, the teachers engaged in the course should pay attention to the improvement of the actual operational capability of ocean transportation business and maritime cases, and can participate in legal practice work properly, and participate in port training and boarding training. In the spare time, the teachers of the research group should also strengthen communication and hold regular exchanges of topics to improve together. In addition, the bilingual teacher's access system should also be strictly controlled. First of all, teachers who apply for bilingual teaching must have certain teaching experience and a high level of teaching. They have already taught the course in Chinese. Secondly, teachers who apply for bilingual teaching should be able to read foreign language textbooks and accurately understand the knowledge content in the textbooks. Eligible teachers should submit an application to the department, review it and submit it to the Academic Affairs Office for approval, and finally approve it by the school.

\subsection{Strengthen teacher-student interaction}

Today's classroom teaching pays more and more attention to the two-way interaction between teachers and students. It has become an important method and means to activate the classroom atmosphere and improve the quality of teaching. There are a large number of case studies in the course "Marine Business and Maritime Law", which is very suitable for students to participate in. In the classroom, you can choose some controversial cases, let the students into several groups, each of them express their opinions and opinions for the party they represent, and reflect the knowledge they have learned to the maximum extent in the discussion process, which can consolidate the students well.

\subsection{Establish a bilingual curriculum evaluation system to strengthen supervision and management of bilingual teaching}

At present, bilingual teaching is still in its infancy, and there are still many problems in the implementation process. This is not unrelated to the supervision and management system that does not have a bilingual teaching curriculum. We believe that the evaluation system of bilingual teaching should be established as soon as possible to strengthen bilingual teaching. Supervision and management to ensure the quality of bilingual teaching. In the evaluation system of bilingual teaching, we believe that timely feedback of teaching information is particularly important. We need to establish a student learning quality testing and analysis system, which can evaluate students' knowledge and ability, the improvement of foreign language level and the satisfaction of the teaching process from the perspective of students and individuals. The course group needs to collect feedback in a timely manner and do a good job of communicating with students and teaching management departments in a timely manner.

\section{References}

[1] Zhou Xiaoming. The unification of maritime law - status quo, problems and countermeasures [J]. World sea Yun, 2004 (4): 36.

[2] Yu Shicheng. Maritime Law Research [M]. Zhuhai: Zhuhai Publishing House, 2006: 12. 
[3] Yu Shihui. Research on bilingual case teaching of "Ocean Shipping Business and Maritime Law" [J]. Navigation Maritime Education Research, 2013 (3) 